\title{
CROSS-CURRENCY BASIS SPREAD AND ITS IMPACT ON CORPORATE LENDING RATES IN THE CZECH BANKING SECTOR*
}

\section{Dušan Staniek ${ }^{a}$}

\begin{abstract}
For successful monetary policy implementation, it is crucial to know the pricing behaviour of banks and the determinants of banks' lending rates. With the onset of the global financial crisis, markets in unsecured lending ceased to provide a reliable level of market costs, while markets in cross-currency products gained significance. The aim of this research is to gauge the extent to which the EUR-CZK cross-currency basis spread is reflected in the corporate lending rates provided by Czech banks. We discovered that just over 50\% of the changes in the basis pass through to the lending rates. The greater part of this passthrough can be identified in EUR lending rates, which are, as a result, higher. In the case of CZK, the negative basis should tend to decrease the lending rates. However, the impact is fairly limited, and we were not able to confirm any significant long-run relationship.
\end{abstract}

Keywords: Interest rate transmission, cross-currency basis spread, lending rates JEL Classification: E43, G15, G21, G32

\section{Introduction}

A thorough examination of the interest rate transmission mechanism (in other words, the interest rate pass-through) is beneficial from several points of view. From a microeconomic perspective, it helps to understand the way commercial banks set retail interest rates for their customers. Furthermore, for the macroeconomist and the policy maker, the effective pass-through mechanism plays a leading role in the traditional interest rate channel of monetary policy. This channel focuses on how central banks' policyinduced changes to interest rates are transmitted into longer-term interest rates, especially

a Prague University of Economics and Business, Faculty of Finance and Accounting, Prague, Czech Republic

Email: xstad05@vse.cz

* The research has been supported by the internal grant VŠE IG102027 and the research project GAČR 18-05244S, Innovative Approaches to Credit Risk Management, which the author gratefully acknowledges. 
those applied to commercial loans, thus affecting macroeconomic aggregates such as investments, output, inflation and employment.

The traditional approach relies on market rates as the starting point for setting rates to banks' customers. However, since the onset of the financial crisis the markets have changed dramatically. Liquidity is zero or low, the term and risk premiums have expanded, and regulation is forcing the banks to limit their trading activities. Construction of yield curves has become a challenge. While the interbank deposit market has been frozen, other market products such as cross-currency swaps and foreign exchange swaps are gaining importance. The difference between the official (or reference) market rates and the yields implied in cross-currency products is called the cross-currency basis spread, and it has become a major factor for constructing bona fide market interest rates.

The aim of this article is to find out whether this cross-currency basis (hereinafter, $\mathrm{CCB}$ ) is finding its way into the pricing of customer products provided by Czech banks, and if so, to what extent. We have chosen the corporate lending rates as the most appropriate representative for the analysis, partly because of their prime importance in the monetary transmission chain, and secondly because (for reasons which will be discussed later), the pass-through of the $\mathrm{CCB}$ should be most visible there. We are not aware of any previous study which has systematically focused on the CCB as a unique element of the pass-through mechanism, despite the fact that the basis can in many cases be larger than the conventional market rate itself or can even turn positive rates into negative ones and vice versa.

The remainder of the paper is organized as follows: the next section reviews the most relevant studies on the topic of interest rate transmission. Section 3 explains the origins of the cross-currency basis and the reasons why it cannot easily be arbitraged away and is therefore becoming a permanent component of yield curves and pricing. Section 4 presents the dataset and develops the model and estimation techniques. The last section presents the findings and points for further discussion.

\section{Literature Review}

Before the global financial crisis starting in 2007, the findings of the main empirical studies on the topic of interest rate transmission showed similar results: the final (longrun) pass-through of market interest rates to customer lending rates is typically complete, i.e., a change in market rates transmits into lending ones by almost $100 \%$ (de Bondt, 2005). Some authors focus on heterogeneity in pricing behaviours of banks (de Graeve et al., 2007; Gambacorta, 2008), or on heterogeneity across countries (Bernhofer and van Treeck, 2013). For the former, the authors discover that liquid and highly capitalized banks are less responsive to changes in the underlying market rates. 
The vast majority of authors recognize the negative impact of the global financial crisis on the tightness of the interest rate transmission. To achieve at least partly satisfactory results, models have to be enhanced by new factors to monitor new determinants having an impact on interest rate curves and the way these affect banks' customer rates. Gambacorta et al. (2015) detect a structural break in the pass-through of money market rates into lending rates after the Lehman collapse. This break is attributed to an increase in the loan mark-up, which was considered constant in the past. To tackle the issue of an unstable mark-up, the authors enhance the standard cointegration model with risk measures a loan delinquency rate and a CDS spread index. The risk characteristics at the bank-level and their impact on the pass-through were investigated by Holton and d'Acri (2015). It is concluded that for riskier banks (e.g., banks with higher CDS spread or banks relying more on borrowing from the Eurosystem), the pass-through coefficients are significantly lower.

Similarly, Paries et al. (2014) argues that standard pass-through models are not capable of explaining increasing levels of heterogeneity in bank lending rates across euro area countries during a time of financial distress; therefore, their model is reinforced with risk factors related to both the banks and their borrowers, and, further, by country-specific sovereign bond spreads, which are named as the main cause of the increased lending costs in certain periphery countries. On the other hand, Hristov et al. (2014) conclude that the observed decrease in the interest rate pass-through does not significantly differ between the EUR core and periphery countries.

Several standard and non-standard monetary measures were introduced by the world's central banks to alleviate the funding constraints commercial banks faced in the aftermath of the crisis. However, Illes and Lombardi (2013) and von Borstel et al. (2016) point out that those measures had only a limited impact. The extraordinary reductions in the policy rates together with other unconventional monetary policies have not been fully transmitted to lending rates for non-financial firms and households. In reaction to the increased risk premiums observed in the lending rates, Illes et al. (2015) introduce an alternative benchmark to measure the funding costs of banks: the weighted average cost of liabilities (WACL). The authors demonstrate that such a real cost indicator is a better starting point for assessing the efficiency of the transmission. That WACL is a better proxy of the banks' funding costs in the case of the Polish market is also confirmed by Kapuściński and Stanisławska (2018). However, the pass-through for lending rates is found to be strong even when using money market rates. The authors conclude that the commercial banks limit the impact of decreasing policy rates on customer deposit rates, and, because deposits are becoming the main source of sustainable funding for banks, the rates paid on them are playing a more significant role in the setting of lending rates. 
Several authors focus specifically on the effectiveness of monetary policy in an environment of very low or even negative interest rates. According to Borio and Gambacorta (2017), lending becomes less responsive to downward adjustments of policy rates in a situation where these rates are already low. Panagopoulos and Tsouma (2019) analyse the first stage of the interest rate transmission, the relationship between the policy rate and money market rates, and they have considered this relationship to be non-operative since the ECB switched its deposit facility rate into negative territory in June 2014. In addition, excess reserves in the banking sector do not automatically lead to an increase in money supply (Kapuściński and Pietryka, 2019). By contrast, Hennecke (2017), when analysing the interest rate channel, suggests that the ultra-low rates helped to reduce the bank margins, and thus the pass-through, even though incomplete, is generally stronger in the new era. This finding can be attributed to the fact that the study concerned Germany - a country that has avoided the sovereign debt crisis and has been perceived as a safe haven.

The situation in the Czech Republic is not significantly different from the development in other European countries, at least if we consider the course of the last 15 years. Studies covering earlier periods suggest a somewhat weaker relationship in both the linkage between the policy and market rates and also in the case of the market to client rates interaction. Brada and Brůna (2004) conclude that in the dynamic environment of disinflation, interbank rates anticipate the changes in the policy rate, and therefore the extent of the ex-post reaction is reduced. The anticipated decrease in inflation, policy rates and, consequently, risk premiums has a positive effect on banks' lending margins. As a result, the drop in rates for new corporate loans overreacts to the decline seen in market rates, and the realized pass-through coefficient exceeds the completeness level of 1 (Brůna, 2007). The pre-crisis pass-through for a block of CEE countries was investigated by Egert et al. (2007). In the case of corporate lending rates, the pass-through shows satisfactory results (with coefficients close to 1 in some cases), with the exception of Poland. Horváth and Podpiera (2012) also confirmed satisfactory results for corporate loans, but indicate a weaker relationship after the appearance of the global financial crisis. The authors had the advantage of working with bank-level data. However, they concluded that the banks' pricing policies are homogenous in the long-term. The crisis and post-crisis period were also assessed separately by Havránek et al. (2016), who concluded that in the period following September 2008 (the Lehman collapse), the long-term pass-through coefficients decreased for all bank products with the exception of mortgages. Concurrently, the clients' mark-ups are seen to be dramatically higher when compared with the situation before the crisis. The authors also confirmed that larger banks, which are more cost-efficient and attract more deposits, tend to smooth interest rates for their customers. As a result, the passthrough is weaker. Mandel and Tomšík (2014) examined whether changes in the CNB 
policy rate had the intended impact on the bank lending and interest rate channel, and they confirmed the efficiency of the monetary policy even in the conditions of excess liquidity in the Czech banking system. Gregor and Melecký (2018) claim to be the first to test the efficiency of the pass-through in the Czech Republic during the period of zerolevel rates and to test the impact of an unconventional monetary policy tool in the form of FX interventions. Their study represents a policy rate approach with further explanatory factors, which are added to the model to tame the time-varying product mark-ups. While most of the factors, e.g., the spread between the government bond yield and the repo rate, which should monitor for changing term premiums and sovereign risks, are working in the anticipated direction, the FX interventions are cited as having "puzzling results". Because the FX interventions and their impact on the Czech financial market play a key role in our research too, we hope that this paper will shed more light on this riddle.

As we have already stated, our research is, to the best of our knowledge, the first of its kind to investigate systematically the direct impact of the cross-currency basis on banks' lending rates. Such an assessment is very closely related to the funding possibilities the banks have in foreign currencies. The international funding factor is taken into consideration by Holland et al. (2017) or by Cook and Steenkamp (2018). The authors use the cost of funds approach, where the level of international funding costs is represented by foreign currency interest rates. Nevertheless, the impact of the cross-currency basis is not gauged explicitly.

Another novelty, which has some common features with our direction of research, is considering sovereign bond yields as the market basis for the pass-through assessment. The sovereign bond markets in different currencies are liquid and closely linked, so the cross-currency products should be reflected in the bond valuations as well. Eller and Reininger (2016) discover a significant impact of bond yields on long-term lending rates in most EU countries. The Czech Republic, however, is one of a few exceptions.

\section{Origins of Cross-currency Basis (CCB) and Its Implications for Lending Rates}

Before the global financial crisis, it was not a difficult task for market participants to agree on what is supposed to be a fair market interest rate. Generally, money markets were operable for periods of up to 1 year, and they served as the source for setting the official reference rates (IBORs). For periods over 1 year, interest rate swap (IRS) quotations were used to prolong the curves. The IRS rates were used without any significant term risk premiums under the general assumption that the long-term fixed rate of a cash product (e.g., a loan) can be hedged just by the IRS, while the real funding can be completed by short-term money market borrowing, which would be rolled over. 
The first tensions on the markets appeared during 2007, and the markets collapsed after the Lehman Brothers' bankruptcy in September 2008. The money markets, which were among the most affected marketplaces, were frozen. While trading in their most typical product, the unsecured interbank deposit, has never really recovered, the significance of using cross-currency products has increased. Baba et al. (2008) explain the mechanism of the FX swaps and cross-currency swaps and how they can be used to overcome funding shortages in a given currency. For smaller markets (such as the CZK) cross-currency products can be the only alternative available to gain liquidity in local currency for periods over 3 months (Staniek, 2016).

The money market rates for unsecured products (resulting in IBORs) and the implied yields of cross-currency products began to differ significantly. At the same time, the construction of yield curves has become a challenge. The single-curve environment has been replaced by multi-curve pricing models (Bianchetti, 2010; Bianchetti and Carlicchi, 2011). Apart from the risk-free rate and various risk premiums, of which credit and liquidity surcharges are the most relevant, the newly constructed curves also need to consider the tenor basis adjustments and the cross-currency basis spread. Baran and Witzany (2014) summarize the peculiarities the market analysts are facing on less developed or illiquid markets.

The easiest way to determine immediately the value of CCB is to check the market quotations of cross-currency basis swaps. These are members of the currency swaps family for which both swap legs are linked to variable interest rates (i.e., floating-to-floating swaps). The swap price is expressed as a mark-up to or discount (generally called a spread) on the variable interest rate of the less significant currency (e.g., PRIBOR $-0.50 \%$ p.a.). The interest rate of the main swap currency is equal to the reference rate flat (i.e., EURIBOR $+0 \%$ p.a.). The main swap currency is determined by market conventions (e.g., for the EUR/USD swap pair it is the USD). The interest period is typically 3 months, which means that the underlying reference variable rate is re-fixed every 3 months. Many useful details about the swap markets and their conventions can be found in Flavell (2010).

Abstracting the value of CCB from the quotation of an FX swap is a bit more complicated. The FX swap price is expressed as the difference between the FX forward and FX spot rates, and the standard (and well-known) formula for Covered Interest Parity (CIP) can be used to calculate the implied interest rates. Once an official reference rate is used in the formula for the main currency, the deviation of the implied yield from the reference rate of the second currency is the value of the CCB. Because of the divergence from the conventional rates, there were growing opinions that the concept of CIP, until then perceived as a physical law in international finance, had been broken. This triggered a new wave of investigations into this phenomenon (Arai et al., 2016; Borio et al., 2018; Iida et al., 2018). 
The size of the CCB differs across currency pairs and is volatile over time. On perfect, effective and risk-free markets it is supposed to oscillate around the zero level; otherwise, the arbitragers would pick up the opportunity to make a profit until the deposit and crosscurrency swap markets were brought into balance again. However, this is now often not happening, and the CCB can reach a significant size (e.g., over 200 b.p. in the case of CZK in early 2017), and it may persist for a long time. Generally, researchers agree that the imbalance in demand and supply for certain currencies is triggering a widening of the CCB (e.g., the squeeze on USD liquidity among European banks), and some of them are trying to specify more concrete drivers of the spread. For example, according to Baran and Witzany (2018) the most relevant drivers of the EUR/USD CCB are credit risk indicators (proxied by the CDS index), general anxiety on the markets (proxied by the equity volatility index VIX) and the EUR/USD FX spot rate. Yet it remains to be explained why the CCB is not arbitraged away. The following points are an attempt to explain the rationale behind this phenomenon.

- $\quad$ Illiquid market for interbank deposits

The risks associated with interbank lending (above all the credit and liquidity risk) are making this product much less attractive compared to trading in fully or partly secured instruments.

- Segregation and inaccessibility of local markets for international players

The official reference rates (IBORs) are usually set by a panel group of local banks (EURIBOR and LIBOR are exceptions, thanks to the wide range of market participants in these global currencies). Due to a higher credit risk associated with lending to those local contributors, the international banks have limited allowances to trade with them. Also, the international names are usually not allowed to take part in the standardized open market operations (e.g., repos) and liquidity-managing facilities organized by the local central bank.

- Regulatory costs and requirements

Banks try to limit their trading activities due to increased regulatory burden and its costs. The costs can be either direct (e.g., contributions to resolution funds, bank levy) or indirect (e.g., associated with increased capital requirements).

- $\quad$ Rigidity in setting the reference rates

The reference rates are computed from indicative quotations provided by a panel of local banks. Usually there are no real trades behind those indications, as the market for some maturities is very thin, and therefore it is difficult to ascertain whether the quotations reflect a reasonable level of banks' funding costs or if they are set to be convenient mainly for the price-maker. That is why ongoing initiatives are taking place to reform the official market benchmarks and the fixing process (see Brousseau et al., 2013; Schrimpf and Sushko, 2019). 
The EUR-CZK cross-currency basis has been firmly based in negative territory since it began to be significant. This means that funding in CZK through cross-currency swaps can be achieved at rates below the official reference rates, but only under the condition that the counterparty willing to pay for CZK is able to provide funds in EUR at the EURIBOR flat rate. We believe that the negative CCB has two main reasons. Partly it is caused by the increased demand of local corporations for EUR funding, but the main reason is certainly the long-standing excess of liquidity in the Czech banking system. This liquidity overflow has accelerated since the start of the FX intervention regime introduced by the CNB in the autumn of 2013. Expectations of CZK appreciation after the termination of the CNB's commitment have led to more speculative sales of EUR and forced the CNB to intensify its purchases. The inflow of fresh CZK into the market has caused an extraordinary widening of the EUR-CZK CCB (seen in Figure 1).

\section{Figure 1: Development of CCB (1Y) and FX interventions}

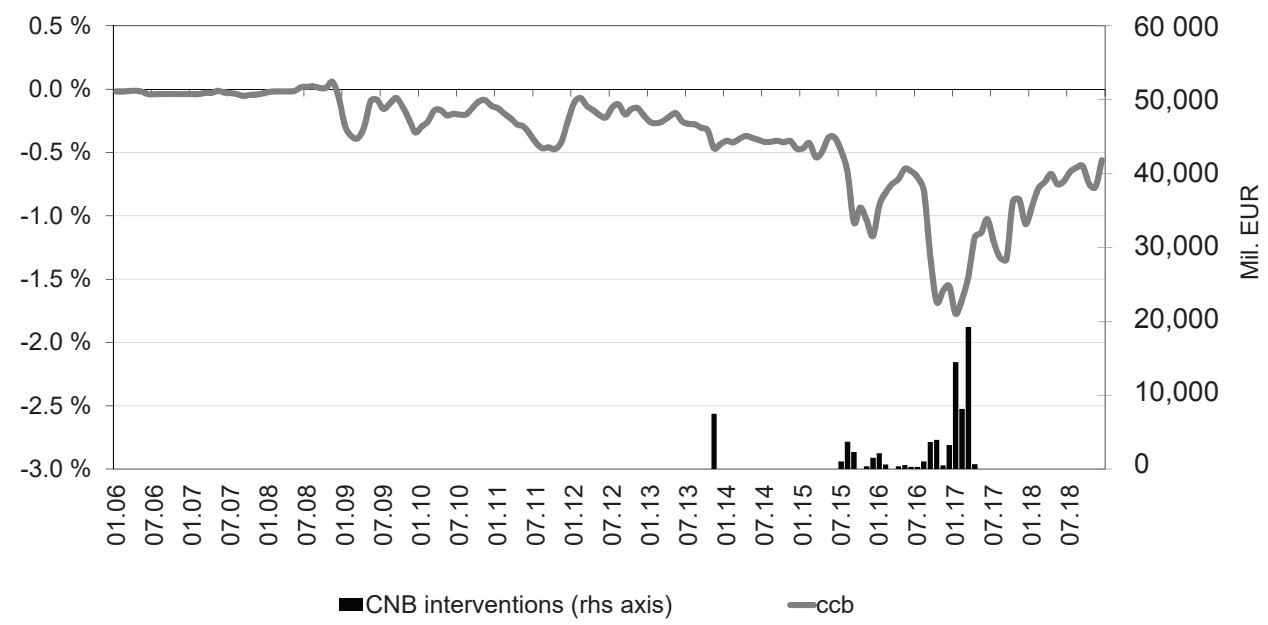

Source: CNB, Thomson Reuters Eikon terminal, author's calculations

Therefore, we would expect the negative CCB to be reflected in the corporate lending rates as follows: either it should increase the EUR lending rates (if the CCB widening is triggered by a shortage of EUR funds in the local market), or it should reduce the CZK lending rates (if the CCB is the result of a liquidity surplus in CZK). The latter is not so straightforward, as the largest Czech banks operate under a liquidity surplus and they are not forced to convert EUR into CZK (using cross-currency products). However, there are also branches of foreign banks operating on this highly competitive market in corporate 
loans. These branches do not usually have many own deposits and they rely on EUR funding provided by their headquarters. As a result, the competition should push the CZK rates lower. Moreover, if the corporate customers are sophisticated enough, they can push their bank lenders to provide them with more favourable financing (CCB included), or they can draw a EUR loan instead of CZK and swap the funds themselves. In the end, the loan markets (in EUR and in CZK) and the market for cross-currency swaps should be heading towards a general equilibrium.

\section{Methodology, Data and Model}

In the preceding chapter we indicated that the widening of the $\mathrm{CCB}$ is generally prompted by a shortage or excess of one of the currencies of which the CCB's pair consists. A proper assessment of the overall impact of the $\mathrm{CCB}$ on bank clients' rates therefore has to consider both currencies involved. We have proposed corporate lending rates as the best candidate for this exercise for a couple of reasons. The amounts in other types of lending products (household term loans, consumer loans and mortgages) provided by Czech banks in EUR are insignificant or negligible. In fact, the same could be stated in the case of deposit products, where only the volumes of one-day deposits (mainly current account balances) are noteworthy. Branches of foreign banks (with good access to international markets), together with local banks, are creating a very competitive environment in the sector of corporate lending, and therefore the CCB pass-through should be most visible here. Other studies too (e.g., Hainz et al., 2014; Havránek et al., 2016) have confirmed the closest relationship between the market rates and lending rates provided to large corporations.

The CNB's database ARAD assembles monthly data for corporate loans provided to non-financial companies. These are classified according to several criteria. We will focus on the category of large loans (above 30 million CZK), which typically covers around $80 \%$ of all new corporate loans taken out in a particular month. Of this amount, usually more than $90 \%$ is provided at a variable rate or at a rate fixed for not more than 1 year. Later we will experience that the lending rates are quite volatile - this is due to the fact that also the aggregated volume of the underlying loans is unstable. The lower volumes increase the probability that large newly drawn loans with extraordinary margins will bias the weighted lending rate.

There is no further breakdown according to the loan maturity in this category, which is why some authors are trying to find the market rate with the highest correlation with the lending rate. In our case we will have two determinants of the loan rate - a market rate and the CCB. We have chosen the $1 \mathrm{Y}$ IRS/3M quotation as the most appropriate representative of the market rate, because it can be easily combined with the CCB seen 
in the cross-currency swap quotations. Naturally the best fit in our case is the market quotation of 1Y EUR-CZK CCB swap, where both legs are based on the variable (3M) rate, and the $\mathrm{CCB}$ is represented as a surcharge to or discount on the variable $\mathrm{CZK}$ rate (3M PRIBOR). The IRS rate plus the CCB spread defines a new level of market funding constructed out of a "low risk" $3 \mathrm{M}$ rate series and reflecting the cross-currency funding element. The market data (IRS, CCB) are taken from the Reuters terminal (brokers' contributions) and are expressed as monthly (unweighted) averages. The data were collected between January 2006 and December 2018, thus comprehensively covering the pre-crisis phase, the global financial crisis and the post-crisis development with exceptional phenomena such as the sovereign debt crisis or the employment of non-standard monetary policy tools.

To build an appropriate model for the pass-through evaluation, we will start with an elementary idea of Rousseas (1985) that the lending rates (lr) of banks are the total of the costs of funds and an interest rate spread, which is called a mark-up or gross margin $(\mathrm{gm})$. The costs of funds are represented in our case by the market rate $(\mathrm{mr})$, which is supposed to be the main determinant of banks' pricing on a competitive market:

$$
l r=g m+m r .
$$

This basic equation is often enhanced with various determinants or factors to control the (time-variable) loan margin and, further, to obtain a more precise assessment of the market costs. We have developed two different approaches to the assessment of the pass-through of the CCB into the lending rates. During the first exercise, we will examine the lending rates in CZK and EUR as if they formed a complex structure at which the banks look during the pricing process. In this case, the CCB will be an element explaining the differences in the banks' gross margins. For this purpose we will define the difference in the gross margin for CZK and EUR as $d g m_{c z k-e u r}$ :

$$
d g m_{c z k-e u r}=g m_{c z k}-g m_{e u r}=\left(l r_{c z k}-m r_{c z k}\right)-\left(l r_{e u r}-m r_{\text {eur }}\right) .
$$

Next, we shall assess the pricing behaviour for CZK and EUR separately, with CCB being a component of the market price. In this exercise we shall develop an independent model for each of those currencies involved.

To decide on the most appropriate model for any of the indicated pass-through relations we need to test the stationarity of the data and, in the next step, to examine possible cointegration between the variables whose relationship we are going to evaluate jointly. For the stationarity test we perform the Augmented Dickey-Fuller test (ADF), where the null hypothesis confirms the existence of a unit root (and thus the non-stationarity of the data), and for robustness we also employ the Kwiatkowski-Phillips-Schmidt-Shin 
test (KPSS), which operates with the alternative null hypothesis, meaning that the time series is stationary. If the investigated time series are integrated of the same order, e.g., I(1), we can follow with cointegration tests. For a single-equation model, the Engle-Granger cointegration can be tested by using a static regression model of the employed time series (Arlt and Arltova, 2009). The residuals we obtain from the model are checked for their integration order - the variables are cointegrated if the residuals are integrated of lower order than the original variables, e.g., I(0). Table 1 summarizes the tests of the data stationarity and cointegration tests of the time series, whose relationship we will examine further.

Table 1: Stationarity and cointegration tests of variables

\begin{tabular}{|c|c|c|c|c|c|c|c|c|}
\hline \multirow[b]{4}{*}{ Variable } & \multicolumn{8}{|c|}{ Stationarity tests } \\
\hline & \multicolumn{4}{|c|}{ ADF: time series has a unit root } & \multicolumn{4}{|c|}{ KPSS: time series is stationary } \\
\hline & \multicolumn{2}{|c|}{$\begin{array}{l}\text { Level } \\
\text { (with intercept) }\end{array}$} & \multicolumn{2}{|c|}{ First difference } & \multicolumn{2}{|c|}{$\begin{array}{l}\text { Level } \\
\text { (with intercept) }\end{array}$} & \multicolumn{2}{|c|}{ First difference } \\
\hline & Test stat & $p$-value & Test stat & $p$-value & Test stat & $p$-value & Test stat & $p$-value \\
\hline$m r_{c z k}$ & -1.182 & $>0.1$ & -5.143 & $<0.01$ & 0.829 & $<0.01$ & 0.245 & $>0.1$ \\
\hline$m r_{\text {eur }}$ & -1.252 & $>0.1$ & -6.177 & $<0.01$ & 0.977 & $<0.01$ & 0.076 & $>0.1$ \\
\hline$c c b$ & -1.835 & $>0.1$ & -9.089 & $<0.01$ & 0.924 & $<0.01$ & 0.089 & $>0.1$ \\
\hline$I r_{c z k}$ & -1.128 & $>0.1$ & -17.01 & $<0.01$ & 0.835 & $<0.01$ & 0.176 & $>0.1$ \\
\hline$I r_{\text {eur }}$ & -1.991 & $>0.1$ & -11.46 & $<0.01$ & 0.890 & $<0.01$ & 0.071 & $>0.1$ \\
\hline$d g m_{c z k-e u r}$ & -6.689 & $<0.01$ & -11.45 & $<0.01$ & 0.591 & 0.023 & 0.056 & $>0.1$ \\
\hline \multirow[t]{4}{*}{$d g m_{c z k-e u r}(s m)$} & -1.575 & $>0.1$ & -10.91 & $<0.01$ & 0.589 & 0.024 & 0.086 & $>0.1$ \\
\hline & \multicolumn{8}{|c|}{ Cointegration tests } \\
\hline & \multicolumn{4}{|c|}{ Static regression } & \multicolumn{4}{|c|}{$\begin{array}{l}\text { Stationarity of regression residuals } \\
\text { (Level, no intercept) }\end{array}$} \\
\hline & \multicolumn{4}{|c|}{$\begin{array}{l}\text { Regression coefficients } \\
\text { ( } p \text {-value in parentheses) }\end{array}$} & \multicolumn{2}{|c|}{$\begin{array}{l}\text { ADF: time series } \\
\text { has a unit root }\end{array}$} & \multicolumn{2}{|c|}{$\begin{array}{l}\text { KPSS: time series } \\
\text { is stationary }\end{array}$} \\
\hline $\begin{array}{l}\text { Regression } \\
\text { equations }\end{array}$ & $\mathbf{a}$ & $\beta$ & $\beta_{1}$ & $\beta_{2}$ & Test stat & $p$-value & Test stat & $p$-value \\
\hline $\begin{array}{l}\operatorname{dgm}_{\text {czk-eur }}=a+ \\
\beta c c b\end{array}$ & $\begin{array}{l}-0.075 \\
(0.099)\end{array}$ & $\begin{array}{c}0.484 \\
(0.000)\end{array}$ & - & - & -7.720 & $<0.01$ & 0.127 & $>0.1$ \\
\hline $\begin{array}{l}I r_{c z k}=a+\beta_{1} m r_{c z k} \\
+\beta_{2} c c b\end{array}$ & $\begin{array}{c}1.820 \\
(0.000)\end{array}$ & - & $\begin{array}{c}0.692 \\
(0.000)\end{array}$ & $\begin{array}{c}0.254 \\
(0.001)\end{array}$ & -3.982 & $<0.01$ & 0.135 & $>0.1$ \\
\hline $\begin{array}{l}\text { Ir } r_{\text {eur }}=\alpha+\beta_{1} m r_{\text {eur }} \\
+\beta_{2} c c b\end{array}$ & $\begin{array}{c}1.680 \\
(0.000)\end{array}$ & - & $\begin{array}{c}0.806 \\
(0.000)\end{array}$ & $\begin{array}{l}-0.242 \\
(0.021)\end{array}$ & -8.248 & $<0.01$ & 0.105 & $>0.1$ \\
\hline
\end{tabular}

Source: Author's calculations 
The results show that all the variables are non-stationary and integrated of order one, i.e., I(1). In the case of the CZK-EUR gross margin difference $\left(d g m_{c z k-e u r}\right)$, the unit root test returned ambivalent results, and, therefore, we performed simple exponential smoothing to refine the series, now called $d g m_{c z k-e u r}(\mathrm{sm})$. After the smoothing, the test results became unambiguous. However, for the sake of consistency, we will still use the unadjusted series in further processing.

The unit root tests applied to the residuals of the static regressions confirm their stationarity, which suggests cointegration between the variables in the chosen relationships. Moreover, the serial correlation test (Breusch-Godfrey LM test) rejected the null hypothesis of no serial correlation of the residuals in the case of all the tested relationships. The presence of the cointegration and serial correlation of residuals justifies using the Autoregressive Distributed Lag model (ARDL) and Error Correction Model (ECM) for further analysis. The ECM allows us to distinguish between the short-term and long-term relationships in the given model. While the short-term relationships are volatile and disappear over time, the long-term one persists - it is an equilibrium to which the variables tend to be attracted in the long-run. The ECM will be derived from the ARDL model using a linear transformation as suggested by Banerjee (1993). The general $\operatorname{ARDL}(\mathrm{m}, \mathrm{n}, \mathrm{p})$ is given by Equation 3:

$$
y_{t}=\alpha_{0}+\sum_{i=1}^{m} \alpha_{i} y_{t-i}+\sum_{j=1}^{p} \sum_{i=0}^{n} \beta_{j, i} x_{j, t-i}+\varepsilon_{t},
$$

where $m$ and $n$ are the maximum lag lengths and $p$ is the number of exogenous variables. The lag lengths $(m, n)$ are determined using the Stepwise Least Squares (STEPLS) regression method - we start with 12 lags for each variable and remove the lags with the largest $p$-value backwards until all remaining variables have $p$-value less than or equal to 0.05 (here $p$-value is the probability or significance value for rejecting the null hypothesis that the given coefficient is zero). During the transformation of the ARDL model to ECM we will develop the long-run equilibrium relationship where $m=n$. In our cases, we will use one or two exogenous variables, and during the STEPLS regression we will find out that the models result in a maximum of 2 lags of the variables used. The ARDL to ECM transformation for $p=1,2$ and $m=n=1$ (Equation 4) and $m=n=2$ (Equation 5) is defined as follows:

$$
\Delta y_{t}=\alpha_{0}+\sum_{j=1}^{p} \beta_{j, 0} \Delta x_{j, t}+\gamma\left(y_{t-n}-\sum_{j=1}^{p} \delta_{j} x_{j, t-n}\right)+\epsilon_{t}
$$




$$
\begin{aligned}
\Delta y_{t}= & \alpha_{0}+\left(\alpha_{1}-1\right) \Delta y_{t-1}+\sum_{j=1}^{p}\left[\beta_{j, 0} \Delta x_{j, t}+\left(\beta_{j, 0}+\beta_{j, 1}\right) \Delta x_{j, t-1}\right]+ \\
& +\gamma\left(y_{t-n}-\sum_{j=1}^{p} \delta_{j} x_{j, t-n}\right)+\epsilon_{t},
\end{aligned}
$$

where

$$
\begin{aligned}
& \gamma=-\left(1-\sum_{i=1}^{m} \alpha_{i}\right) \\
& \delta_{j}=\frac{\sum_{i=0}^{n} \beta_{j, i}}{1-\sum_{i=1}^{m} \alpha_{i}}, j=1,2 .
\end{aligned}
$$

The variables with the delta symbol represent the short-run dynamics, while the expression in the last parentheses describes the long-run relationship. Coefficients $\delta_{j}$ measure the long-run pass-through and $\gamma$ is the speed of adjustment (also called the loading factor) towards the long-run equilibrium.

\subsection{Estimation of complex CCB pass-through}

For the overall assessment of the CCB pass-through to CZK and EUR lending rates we will start with Equation 1, where the gross margin $(\mathrm{gm})$ was replaced by a net credit margin $(\mathrm{ncm})$ extended by various risk premiums:

$$
I r=g m+m r=n c m+c r p+l r p+o r p+m r .
$$

The variable $c r p$ stands for the credit risk premium, $\operatorname{lrp}$ for liquidity risk premium and orp represents other (residual) risk premiums.

According to Baran and Witzany (2014), the risk premiums may vary depending on the underlying currency, which is why we will construct two identical equations, one for CZK and the second for EUR. By subtracting the second equation from the first one, after a slight regrouping of the variables, we obtain Equation 9:

$$
\begin{aligned}
& \left(l r_{c z k}-m r_{c z k}\right)-\left(l r_{e u r}-m r_{e u r}\right)=\left(c r p_{c z k}+l r p_{c z k}+o r p_{c z k}\right)-\left(c r p_{e u r}+l r p_{e u r}+o r p_{e u r}\right)+ \\
& +\left(n c m_{c z k}-n c m_{e u r}\right) .
\end{aligned}
$$

The left-hand side of the formula represents the difference between the CZK and EUR gross margin $\left(d g m_{c z k-e u r}\right)$, a variable which we have already submitted to scrutiny during the stationarity and cointegration tests. The last expression in parentheses on the right-hand side, the difference in the net credit margins, should generally be equal to zero, and thus 
it can be ignored. What remains on the right-hand side represents the difference in currency specific risk premiums, and, in fact, its value should be equal to the value of the CCB. Equation 9 therefore shows a linear and straightforward dependence of the gross margins' difference (endogenous) on the CCB (exogenous), and can be tested by using Equation 3, where $y=d g m_{c z k-e u r}$ and $x_{1}=c c b$. The coefficient $\alpha_{0}$ in the equation represents a regression constant (or intercept), which, we would suggest, should be close to zero. Figure 2 shows the development of the two series over the examined period.

Figure 2: Development of CCB and CZK-EUR gross margin difference

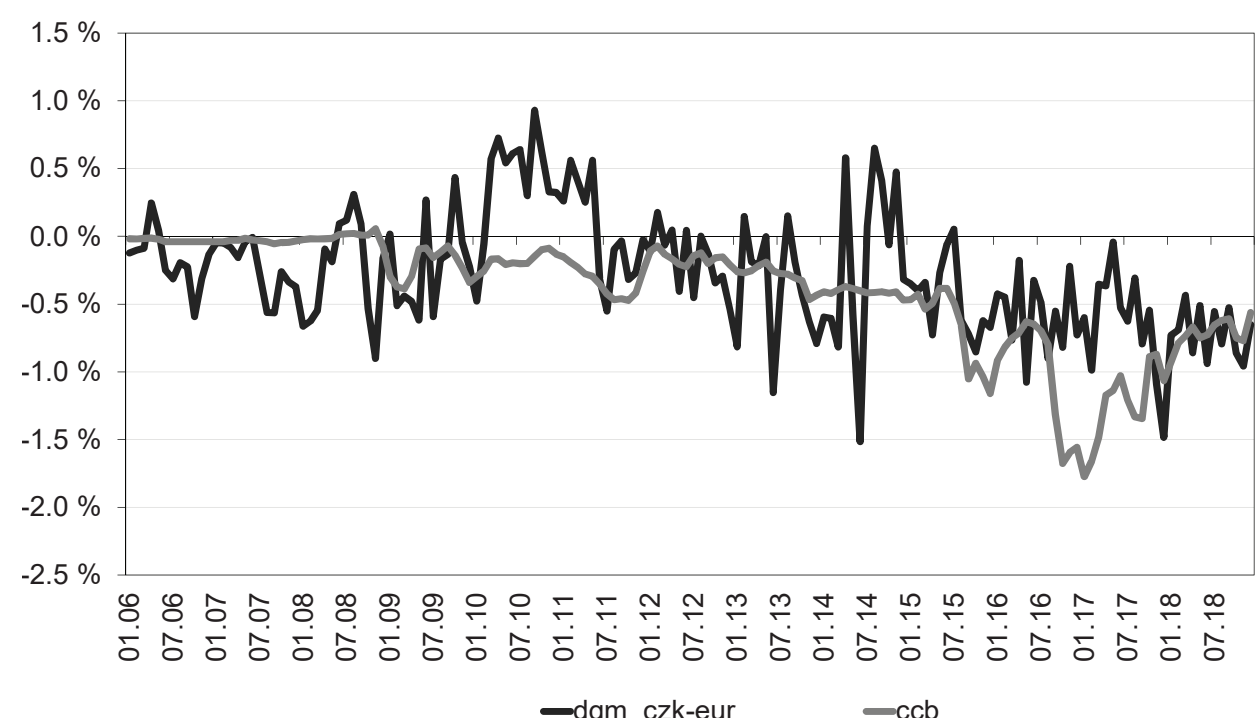

Source: CNB/ARAD, Thomson Reuters Eikon terminal, author's calculations

To test the relationship, we will develop an ARDL model (Equation 3) for one exogenous variable $(p=1)$ and subsequently the corresponding ECM. While analysing the raw data we identified an extraordinary spike in the EUR lending rate in June 2014. Such an outlier can be caused by a large loan with an extraordinary margin (usually a loan syndication), which then distorts the monthly weighted average rate. We used a dummy variable $(d 1)$ bearing the value 1 for this particular observation (and 0 for all others). After this enhancement, the model passed all residual diagnostic tests - for serial correlation (Breusch-Godfrey LM test), normality (Jarque-Bera) and heteroscedasticity (ARCH). Table 2 summarizes the outcome of the estimated models. Coefficients with $p$-value less than 0.05 are exempted from the model. 
Table 2: Results of ARDL and ECM model

\begin{tabular}{|c|c|c|c|c|c|}
\hline \multicolumn{6}{|c|}{ ARDL } \\
\hline Equation term & Coefficient & Value & Std. error & $t$-stat & $p$-value \\
\hline Intercept & $a_{0}$ & -0.025 & 0.041 & -0.613 & 0.541 \\
\hline$d g m_{c z k-e u r, t-1}$ & $a_{1}$ & 0.341 & 0.079 & 4.309 & 0.000 \\
\hline$d g m_{c z k-e u r, t-2}$ & $a_{2}$ & 0.169 & 0.079 & 2.129 & 0.035 \\
\hline$c c b t$ & $\beta_{1,0}$ & 0.252 & 0.078 & 3.230 & 0.002 \\
\hline$d 1_{t}$ & $\beta_{2,0}$ & -1.290 & 0.360 & -3.582 & 0.001 \\
\hline \multicolumn{6}{|c|}{ ECM } \\
\hline \multicolumn{3}{|c|}{ Short-term dynamics } & \multicolumn{3}{|c|}{ Long-run relationship } \\
\hline Equation term & Coefficient & Value & Equation term & Coefficient & Value \\
\hline$\Delta d g m_{c z k-e u r, t-1}$ & $\left(a_{1}-1\right)$ & -0.659 & $c c b_{t-2}$ & $\delta_{1}$ & 0.515 \\
\hline$\Delta c c b t$ & $\beta_{1,0}$ & 0.252 & Loading factor & $\gamma$ & -0.490 \\
\hline$\Delta c c b_{t-1}$ & $\beta_{1,0}$ & 0.252 & \multicolumn{3}{|c|}{-} \\
\hline
\end{tabular}

Source: Author's calculations

The long-run pass-through coefficient indicates that just over $50 \%$ of the changes in the $\mathrm{CCB}$ are reflected in the loans pricing patterns of the banks. The loading factor is close to the middle of the interval $(0,1)$ and suggests an ordinary speed of the adjustment.

\subsection{Estimation of CCB pass-through to lending rates in each individual currency}

In this section we will try to figure out whether the CCB finds its way into CZK or, rather, into EUR lending rates, and how strong the pass-through relationship is for each of those currencies. To develop a proper ARDL model, we started with Equation 1. Originally we tried to enhance the model not only with the CCB as a new exogenous factor, as we also tried to add some liquidity (e.g., 1Y IBOR - IRS spread) and credit risk (CDS index) gauges with the aim of getting control over the time-variable customer gross margin $(\mathrm{gm})$. However, these additional risk measures did not contribute to a more reliable model, and in some cases the sign of the coefficients (for certain variables) was even the opposite of the expected one. We therefore ended up with just two exogenous variables $(m r$ and $c c b$ ), as shown in Equation 10. The value of $n c m$ together with other unknown factors will be covered by the model constant. 


$$
l r=n c m+m r+c c b .
$$

Analogously to the model construction in the previous chapter, Equations 3, 4 and 5 are used to develop a proper ARDL model, where $y=l r, x_{1}=c c b$ and $x_{2}=m r$, and the corresponding ECM separately for EUR and CZK. Figures 3 and 4 show the series development over the examined period. Tables 3 and 4 summarize the outcome of the estimated models. Again, coefficients with $p$-value less than 0.05 are exempted from the model. To tackle the extraordinary observation in the EUR lending rates for June 2014, a dummy variable was used in the same way as described in the previous chapter.

Figure 3: Development of EUR lending rates, EUR market rates and CCB

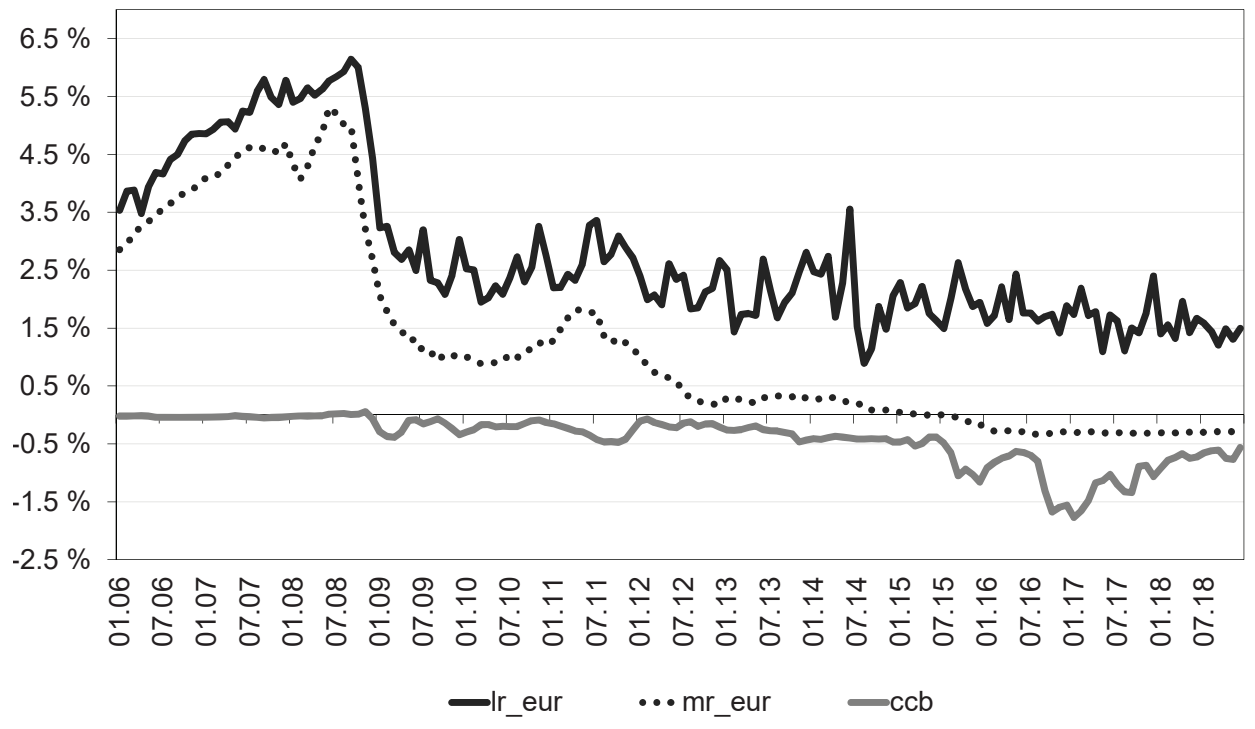

Source: CNB/ARAD, Thomson Reuters Eikon terminal, author's calculations 
Figure 4: Development of CZK lending rates, CZK market rates and CCB

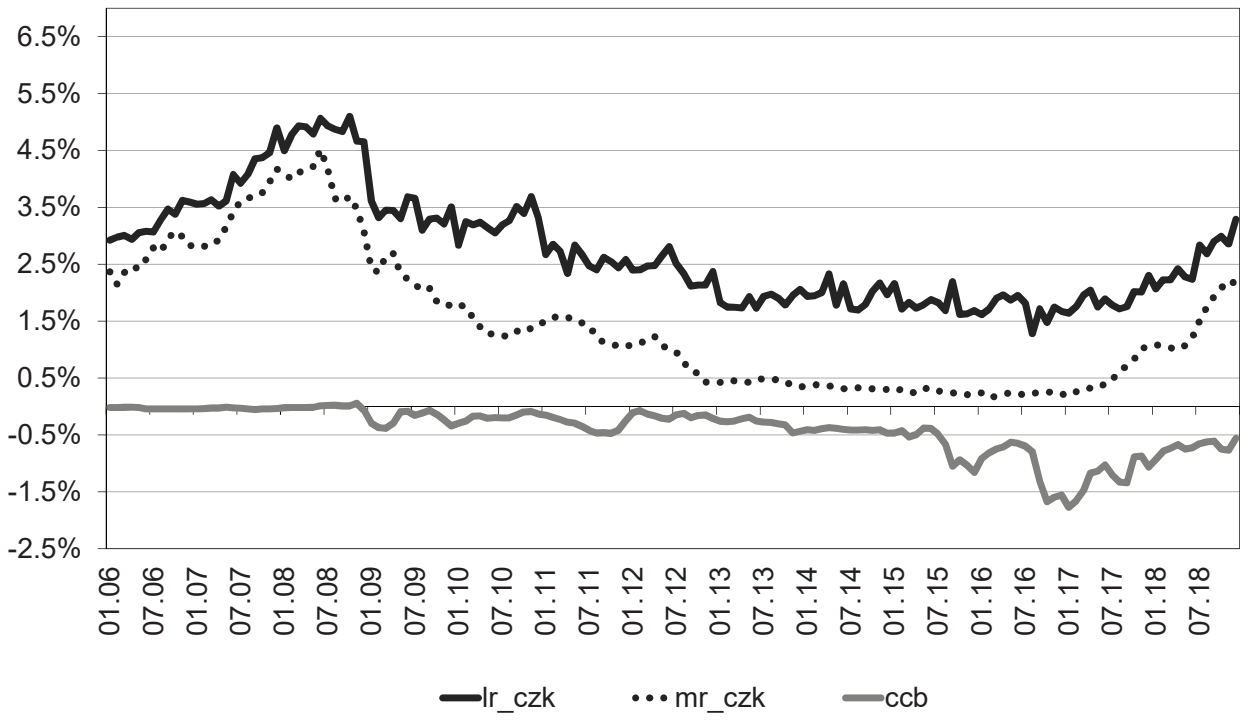

Source: CNB/ARAD, Thomson Reuters Eikon terminal, author's calculations

Table 3: Results of ARDL and ECM model for EUR

\begin{tabular}{|c|c|c|c|c|c|}
\hline \multicolumn{6}{|c|}{ ARDL } \\
\hline Equation term & Coefficient & Value & Std. error & t-stat & $p$-value \\
\hline Intercept & $a_{0}$ & 1.016 & 0.124 & 8.185 & 0.000 \\
\hline$I r_{\text {eur }, t-1}$ & $a_{1}$ & 0.367 & 0.061 & 6.017 & 0.000 \\
\hline$c c b_{t}$ & $\beta_{1,0}$ & -0.193 & 0.089 & -2.166 & 0.032 \\
\hline $\boldsymbol{m} r_{\text {eur }, \mathrm{t}}$ & $\beta_{2,0}$ & 0.525 & 0.053 & 9.987 & 0.000 \\
\hline$d 1_{t}$ & $\beta_{3,0}$ & 1.520 & 0.341 & 4.461 & 0.000 \\
\hline \multicolumn{6}{|c|}{ ECM } \\
\hline \multicolumn{3}{|c|}{ Short-term dynamics } & \multicolumn{3}{|c|}{ Long-run relationship } \\
\hline Equation term & Coefficient & Value & Equation term & Coefficient & Value \\
\hline$\Delta c c b_{t}$ & $\beta_{1,0}$ & -0.193 & $c c b_{t-1}$ & $\delta_{1}$ & -0.305 \\
\hline$\Delta m r_{t}$ & $\beta_{2,0}$ & 0.525 & $m r_{t-1}$ & $\delta_{2}$ & 0.829 \\
\hline \multicolumn{3}{|c|}{-} & Load. factor & $\gamma$ & -0.633 \\
\hline
\end{tabular}

Source: Author's calculations 
Table 4: Results of ARDL and ECM model for CZK

\begin{tabular}{|c|c|c|c|c|c|}
\hline \multicolumn{6}{|c|}{ ARDL } \\
\hline Equation term & Coefficient & Value & Std. error & t-stat & $p$-value \\
\hline Intercept & $a_{0}$ & 0.557 & 0.110 & 5.072 & 0.000 \\
\hline$I r_{c z k, t-1}$ & $a_{1}$ & 0.410 & 0.077 & 5.338 & 0.000 \\
\hline$I r_{c z k, t-2}$ & $a_{2}$ & 0.244 & 0.069 & 3.531 & 0.001 \\
\hline$c c b_{t-1}$ & $\beta_{1,1}$ & 0.377 & 0.163 & 2.311 & 0.022 \\
\hline$c c b_{t-2}$ & $\beta_{1,2}$ & -0.373 & 0.162 & -2.307 & 0.023 \\
\hline$m r_{c z k, t}$ & $\beta_{2,0}$ & 0.268 & 0.038 & 6.966 & 0.000 \\
\hline \multicolumn{6}{|c|}{ ECM } \\
\hline \multicolumn{3}{|c|}{ Short-term dynamics } & \multicolumn{3}{|c|}{ Long-run relationship } \\
\hline Equation term & Coefficient & Value & Equation term & Coefficient & Value \\
\hline$\Delta / r_{c z k, t-1}$ & $\left(a_{1}-1\right)$ & -0.590 & $\mathbf{c c b}_{t-2}$ & $\delta_{1}$ & 0.011 \\
\hline$\Delta c c b_{t-1}$ & $\beta_{1,1}$ & 0.377 & $m r_{t-2}$ & $\delta_{2}$ & 0.775 \\
\hline$\Delta m r_{t}$ & $\beta_{2,0}$ & 0.268 & Load. factor & Y & -0.346 \\
\hline$\Delta m r_{t-1}$ & $\beta_{2,0}$ & 0.268 & \multicolumn{3}{|c|}{-} \\
\hline
\end{tabular}

Source: Author's calculations

In the case of EUR only the first lag of the variable $l r$ could be justified in ARDL, and no lags were employed for either of the exogenous variables. As a result, the long-run relationship of the ECM model is expressed with all variables lagged by one month. While the pass-through of the traditional component of a bank's pricing, the common market rate, is relatively strong, the changes in CCB become part of the EUR lending rates from approximately $30 \%$ (as expected, CCB is increasing the lending rates). In the case of CZK we were not even able to confirm any significant size of the CCB pass-through into corporate lending. Here the common market rate remains the only variable with an explanatory value. Moreover, the speed of the adjustment is lower than in the case of EUR.

\section{Conclusions and Discussion}

A functional interest rate pass-through mechanism together with a workable bank lending channel are crucial preconditions for the effective transmission of monetary policy into the real economy. In our research we focus primarily on the interest rate transmission 
channel, specifically on the manner of setting banks' lending rates for corporate customers. We follow the market rates approach, which defines the market rates as the main basis of banks' pricing patterns. However, since the onset of the global financial crisis the markets have changed. Unsecured interbank funding has become onerous, and the liquidity is low or zero. It is therefore also questionable what the bona fide market rate is. In such a situation, cross-currency products (such as FX swaps and cross-currency swaps) are gaining in significance, because they are associated with lower risk premiums, while their liquidity remains satisfactory. As a result, the cross-currency basis has become an important component of the yield curves and is consequently a new factor to be considered during the analysis of the interest rate pass-through.

The novelty and main contribution of this research is that it assesses the relationships between the banks' lending rates and the market rates, including the new pricing component, the cross-currency basis (CCB). Regarding the common market rates (IBOR based), our results are in line with the vast majority of post-crisis studies, which discover a weaker (incomplete) pass-through during and after the financial crisis. However, the relationship is still fairly strong and satisfactory. In our case, which focused on the Czech banking sector, the long-run pass-through of the common market rates has reached $83 \%$ in the case of EUR lending rates and $78 \%$ in the case of CZK. Nevertheless, the situation is different for the CCB. First, we tried to assess the pricing behaviour of Czech banks complexly, with $\mathrm{CCB}$ being an explanatory variable for the difference in the gross margin of EUR and CZK lending rates. Here we found out that just over $50 \%$ of the changes in the CCB are reflected in the gross margins of the lending rates. Next we tried to distinguish whether the basis is finding its way into the EUR lending rates or, rather, into the CZK ones. In the case of EUR rates, we were able to confirm a long-run relationship with a CCB passthrough coefficient around $30 \%$. As a result, the negative CCB tends to increase the EUR lending rates. We would expect the remaining part of the overall pass-through to be part of the CZK lending rates. However, here we were not able to confirm a significant long-run relationship. The negative CCB should be making the lending rates more favourable for the banks' customers, which is not the case. This finding shed some light on the studies, which did not explicitly examine the role of the CCB, but analysed other factors which were supposed to have similar effects on the banks' pricing - the CZK FX interventions and the level of bond yields. Although the FX interventions caused an extraordinary excess of liquidity in the Czech banking sector, thus affecting both the value of the $\mathrm{CCB}$ and the yields of Czech government bonds, the impact on the lending rates seems to be fairly limited. On the other hand, this study confirms that more sophisticated corporate customers should be able to arrange a more favourable CZK financing - by drawing a EUR loan and converting the funds into CZK (using cross-currency products). 
The authors, working with bank-level data, confirmed different pricing approaches based on different banks' determinants. Cash-rich banks are smoothing the lending rates for their customers. We believe that such determinants are playing a role also in the $\mathrm{CCB}$ pass-through, which could be the subject of a follow up study. Banks with a large amount of deposits on their balance sheet are supposed to be less responsive to changes in the market rates (CCB included). On the other hand, branches of international banks are relying on their foreign currency sources provided by their parent companies, and therefore the $\mathrm{CCB}$ is expected to be play a more significant role here.

\section{References}

Arai, F., Makabe, Y., Okawara, Y., Nagano, T. (2016). Recent Trends in Cross-currency Basis. Bank of Japan Review Series, 16-E-7.

Arlt, J., Arltová, M. (2009). Ekonomické časové řady. Praha: Professional Publishing. ISBN 978-80-86946-85-6.

Baba, N., Packer, F., Nagano, T. (2008). The Spillover of Money Market Turbulence to FX Swap and Cross-currency Swap Markets. BIS Quarterly Review, March, 73-86.

Banerjee, A. (1993). Co-integration, Error Correction, and the Econometric Analysis of Non-stationary Data. New York: Oxford University Press. ISBN 0-19-828810-7.

Baran, J., Witzany, J. (2014). Konstrukce výnosových křivek v pokrizovém období. Politická ekonomie, 62(1), 67-99, https://doi.org/10.18267/j.polek.938

Baran, J., Witzany, J. (2018). Analysing Cross-Currency Basis Spreads. Ekonomický časopis (Journal of Economics), 66(10), 1002-1030.

Bernhofer, D., van Treeck, T. (2013). New Evidence of Heterogeneous Bank Interest Rate Pass-through in the Euro Area. Economic Modelling, 100(35), 418-429, https://doi.org/10.1016/j.econmod.2013.07.020

Bianchetti, M. (2010). Two Curves, One Price. Risk, 23(8), 66-72.

Bianchetti, M., Carlicchi, M. (2011). Interest Rates after the Credit Crunch: Multiple Curve Vanilla Derivatives and SABR. Capco Journal of Financial Transformation, Applied Finance, 32.

Borio, C., Gambacorta, L. (2017). Monetary Policy and Bank Lending in a Low Interest Rate Environment: Diminishing Effectiveness? Journal of Macroeconomics, 54(Part B), 217-231, https://doi.org/10.1016/j.jmacro.2017.02.005

Borio, C. E. V., Iqbal, M., McCauley, R. N., McGuire, P., Sushko, V. (2018). The Failure of Covered Interest Parity: FX Hedging Demand and Costly Balance Sheets. BIS. Working Papers No. 590. http://doi.org/10.2139/ssrn.2910319

Brada, J., Brůna, K. (2004). Analýza citlivosti referenčních úrokových sazeb PRIBOR na změny repo sazby České národní banky. Politická ekonomie, 52(5), 601-622, https://doi.org/10.18267/j.polek.478 
Brousseau, V., Chailloux, A., Durré, A. (2013). Fixing the Fixings: What Road to a More Representative Money Market Benchmark? International Monetary Fund. Working Paper No. 13/131, https://doi.org/10.5089/9781484306772.001

Brůna, K. (2007). Úrokový transmisní mechanismus a řízení úrokové marže bank v kontextu dezinflační politiky České národní banky. Politická ekonomie, 55(6), 829-851, https://doi.org/10.18267/j.polek.626

Cook, B., Steenkamp, D. (2018). Funding Cost Pass-through to Mortgage Rates. Reserve Bank of New Zealand. Notes Series AN2018/02.

De Bondt, G. (2005). Interest Rate Pass-Through: Empirical Results for the Euro Area. German Economic Review, 6(1), 37-78, https://doi.org/10.1111/j.1465-6485.2005.00121.x

De Graeve, F., De Jonghe, O., Vennet, R. V. (2007). Competition, Transmission and Bank Pricing Policies: Evidence from Belgian Loan and Deposit Markets. Journal of Banking \& Finance, 31(1), 259-278, https://doi.org/10.1016/j.jbankfin.2006.03.003

Eller, M., Reininger, T. (2016). The Influence of Sovereign Bond Yields on Bank Lending Rates: the Pass-through in Europe. Focus on European Economic Integration, 2, 54-78.

Égert, B., Crespo-Cuaresma, J., Reininger, T. (2007). Interest rate pass-through in central and Eastern Europe: Reborn from ashes merely to pass away? Journal of Policy Modeling, 29(2), 209-225, https://doi.org/10.1016/j.jpolmod.2007.01.005

Flavell, R. (2010). Swaps and other Derivatives. 2nd ed. Chichester, West Sussex, UK: Wiley. ISBN 978-0-470-72191-9.

Gambacorta, L. (2008). How Do Banks Set Interest Rates? European Economic Review, 52(5), 792-819, https://doi.org/10.1016/j.euroecorev.2007.06.022

Gambacorta, L., Illes, A., Lombardi, M. J. (2015). Has the transmission of policy rates to lending rates changed in the wake of the global financial crisis? International Finance, 18(3), 263-280, https://doi.org/10.1111/infi.12074

Gregor, J., Melecký, M. (2018). The Pass-through of Monetary Policy Rate to Lending Rates: The Role of Macro-Financial Factors. Economic Modelling, 73, 71-88, https://doi.org/10.1016/j.econmod.2018.03.003

Hainz, C., Horvath, R., Hlaváček, M. (2014). The Interest Rate Spreads in the Czech Republic: Different Loans, Different Determinants? Economic Systems, 38(1), 43-54, https://doi.org/10.1016/j.ecosys.2013.10.002

Havránek, T., Iršová, Z., Lešanovská, J. (2016). Bank Efficiency and Interest Rate Pass-through: Evidence from Czech loan Products. Economic Modelling, 54, 153-169, https://doi.org/10.1016/j.econmod.2016.01.004

Hennecke, P. (2017). The Interest Rate Pass-through in the Low Interest Rate Environment: Evidence from Germany. Thünen-Series of Applied Economic Theory. Working Paper No. 151.

Holland, Q., Liu, B., Roca, E. (2017). Australian Bank Mortgage Price-Setting Behaviour Pre-and Post-GFC: Does International Funding Cost Matter? SSRN. Working Paper No. 2979069, http://doi.org/10.2139/ssrn.2979069 
Holton, S., Rodriguez d'Acri, C. (2015). Jagged Cliffs and Stumbling Blocks: Interest Rate Passthrough Fragmentation during the Euro Area Crisis. European Central Bank. Working Paper No. 1850.

Horváth, R., Podpiera, A. (2012). Heterogeneity in Bank Pricing Policies: The Czech Evidence. Economic Systems, 36(1), 87-108, https://doi.org/10.1016/j.ecosys.2011.03.002

Hristov, N., Hülsewig, O., Wollmershäuser, T. (2014). The Interest Rate Pass-through in the Euro Area during the Global Financial Crisis. Journal of Banking \& Finance, 48, 104-119, https://doi.org/10.1016/j.jbankfin.2014.08.004

lida, T., Kimura, T., Sudo, N. (2018). Deviations from Covered Interest Rate Parity and the Dollar Funding of Global Banks. International Journal of Central Banking, 14(4), 275-325.

Illes, A., Lombardi, M. J. (2013). Interest Rate Pass-through since the Financial Crisis. BIS Quarterly Review, September.

Illes, A., Lombardi, M., Mizen, P. (2015). Why did Bank Lending Rates Diverge from Policy Rates after the Financial Crisis? BIS. Working Paper No. 486.

Kapuściński, M., Pietryka, I. (2019). The Impact of the Excess Reserves of the Banking Sector on Interest Rates and Money Supply in Poland. Narodowy Bank Polski. Working Papers No. 300.

Kapuściński, M., Stanisławska, E. (2018). Measuring Bank Funding Costs in the Analysis of Interest Rate Pass-through: Evidence from Poland. Economic Modelling, 70, 288-300, https://doi.org/10.1016/j.econmod.2017.11.009

Mandel, M., Tomšík, V. (2014). Monetary Policy Efficiency in Conditions of Excess Liquidity Withdrawal. Prague Economic Papers, 23(1), 3-23, https://doi.org/10.18267/j.pep.470

Panagopoulos, Y., Tsouma, E. (2019). The Effect of Negative Policy Rates on the Interest-rate pass-through Mechanism in the Eurozone. Review of Keynesian Economics, 7(2), 247-262, https://doi.org/10.4337/roke.2019.02.09

Pariès, M. D., Moccero, D., Krylova, E., Marchini, C. (2014). The Retail Bank Interest Rate Passthrough: The Case of the Euro Area during the Financial and Sovereign Debt Crisis. European Central Bank. Occasional Paper No. 155.

Rousseas, S. (1985). A Markup Theory of Bank Loan Rates. Journal of Post Keynesian Economics, 8(1), 135-144, https://doi.org/10.1080/01603477.1985.11489549

Schrimpf, A., Sushko, V. (2019). Beyond LIBOR: a Primer on the New Benchmark Rates. BIS Quarterly Review, March.

Staniek, D. (2016). The Czech Crown Money Market as the Source for Pricing Customer Cash Products. European Financial and Accounting Journal, 11(3), 139-154, https://doi.org/10.18267/j.efaj.168

Von Borstel, J., Eickmeier, S., Krippner, L. (2016). The Interest Rate Pass-through in the Euro Area during the Sovereign Debt Crisis. Journal of International Money and Finance, 100(68), 386-402, https://doi.org/10.1016/j.jimonfin.2016.02.014 